\title{
Beyond the personal-anonymous divide: agency relations in powers of attorney in France in the eighteenth and nineteenth centuries ${ }^{1}$ (
}

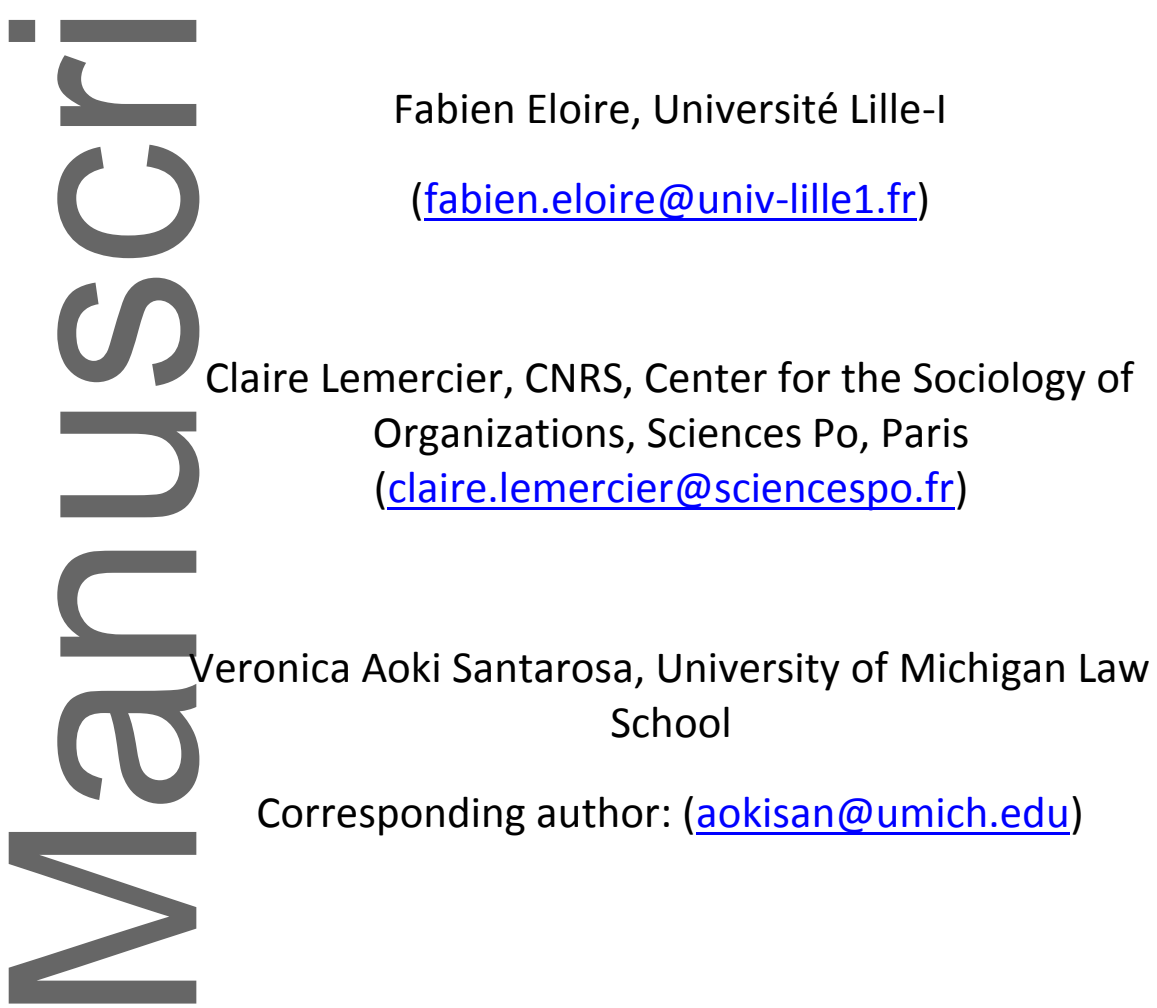

Abstract: Powers of attorney are often interpreted as evidence of trust among the parties involved. We build a novel dataset of notarized powers of attorney, capturing a wide variety of agency relationships in four large French commercial cities in the eighteenth and nineteenth centuries, to test hypotheses on the relational basis of economic relationships. We find little support for the idea

\footnotetext{
${ }^{1}$ We thank James Fenske, Timothy Guinnane, James Hines, Paul Lagneau-Ymonet, Naomi Lamoreaux, William Miller, Francesca Trivellato, Lisbeth Wallmann and seminar participants of The 9th Meeting of the Caltech Early Modern Group for helpful comments. Hunter Harris provided excellent research assistance. This working paper is part of a wider research project, Fiduciae, funded by the French National Agency for Research, and led by Arnaud Bartolomei: see http://cmmc-nice.fr/recherches-2/programmes-finances-2/fiduciae/. We acknowledge his contribution as well as that of other members of the team, especially Boris Deschanel, Matthieu de Oliveira, Nadège Sougy. Bartolomei and Deschanel, along with the authors, directly took part in the collection of the data from archival material.
}

This is the 1 , manuscript accepted for publication and has undergone full peer review but has not been through the cupyediting, typesetting, pagination and proofreading process, which may lead to differences between this version and the Version of Record. Please cite this article as doi: 10.1111/ehr.12784.

This article is protected by copyright. All rights reserved. 
of a radical shift from personal to anonymous relationships during our period. Our results point to more nuanced transformations. The preference for proxies in the same occupation as the principal somewhat declined, while professional proxies emerged and principals used relational chains, especially involving notaries, to find proxies.

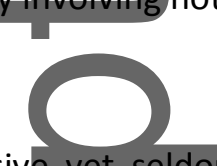

A pervasive yet seldom scrutinized view in economic history and sociology holds great sway in

descriptions of the transition to the modern period. ${ }^{2}$ This narrative of modernity contrasts the premodern world's reliance on private-order, personal-based modes of interaction, to which lessdeveloped societies are confined, with the individualistic framework of impersonal exchanges enabled by formal institutions. North and others, for instance, echo Weber's account of the developmental path of societies in which modernization is characterized by 'the replacement of a fraternal by a business relationship, i.e., of a status contract by a purposive contract' ${ }^{3}$ This neoinstitutionalist narrative, which views the replacement of personal ties by anonymous market exchanges as a condition for economic development, has profoundly influenced the dominant accounts of how societies evolve. ${ }^{4}$ Contemporary actors had already described and debated these transformations. Adam Smith praised the move away from noncommercial societies, in which personal relationships could imply dependence, to more impersonal commercial societies, which he equated with freedom. ${ }^{5}$ Others, however, feared that trust, and therefore credit, would collapse in the context of easily negotiable bills of exchange, corporations with large numbers of shares, and professional agents paid to perform the duties of a proxy, instead of friends representing friends.

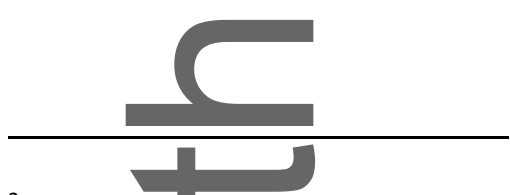

${ }^{2}$ Hoffman et al., Priceless markets; and Leunig et al., 'Networks', are among the few works that have examined empirically the significance of personal ties over time for credit and labour markets, respectively.

${ }^{3}$ North, Understanding; Dixit, 'On modes'; Polanyi, Great Transformation; Weber, Economy and society, p. 709.

${ }^{4}$ Greif, Institutions, for instance, contrasts the intragroup trust based on religious ties among the Maghribi traders to the rational and individualistic institutions of the Genoese, seen as conditions for the commercial revolution and Western growth.

${ }^{5}$ Berry et al., eds., Adam Smith.

This article is protected by copyright. All rights reserved. 
They viewed these trends as symptoms of a change from a traditional to a money-driven, possibly faithless society. ${ }^{6}$

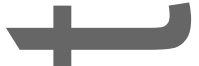

Most historians would certainly dismiss as too crude this storyline of a radical shift from personal relationships based on kinship, religion, or ethnicity to more anonymous, self-interested

a rationship

ones. However, the divide between 'early modern' and 'modern' history implicitly validates it. Recent studies in early modern history have stressed the ways in which personal relationships could mitigate uncertainties or information asymmetries in economic history. They more or less explicitly assume that such relationships were not used in later periods. ${ }^{7}$

The modernization narrative attributes this allegedly inexorable move of Western societies - from personal transactions to anonymous markets - to a build-up of structural changes that, in France, arguably culminated at the turn of the nineteenth century. The French Revolution fashioned a new legal system by abolishing the privileges of the nobility in 1789 and the guilds in 1791, and, with these, the old social order that rested on status. The Napoleonic codification of the 1800s promoted more impersonal market relationships by clarifying property rights. ${ }^{8}$ At the same time, profound developments in the organization of commerce accompanied the Industrial Revolution, fueling the emergence of competitive and impersonal markets. ${ }^{9}$ Internally, the opening of canals and railways from 1800 to 1850 fostered market expansion. Externally, the growth in transatlantic trade in the eighteenth century arguably tested the limits of personal networks and social sanctions. If the

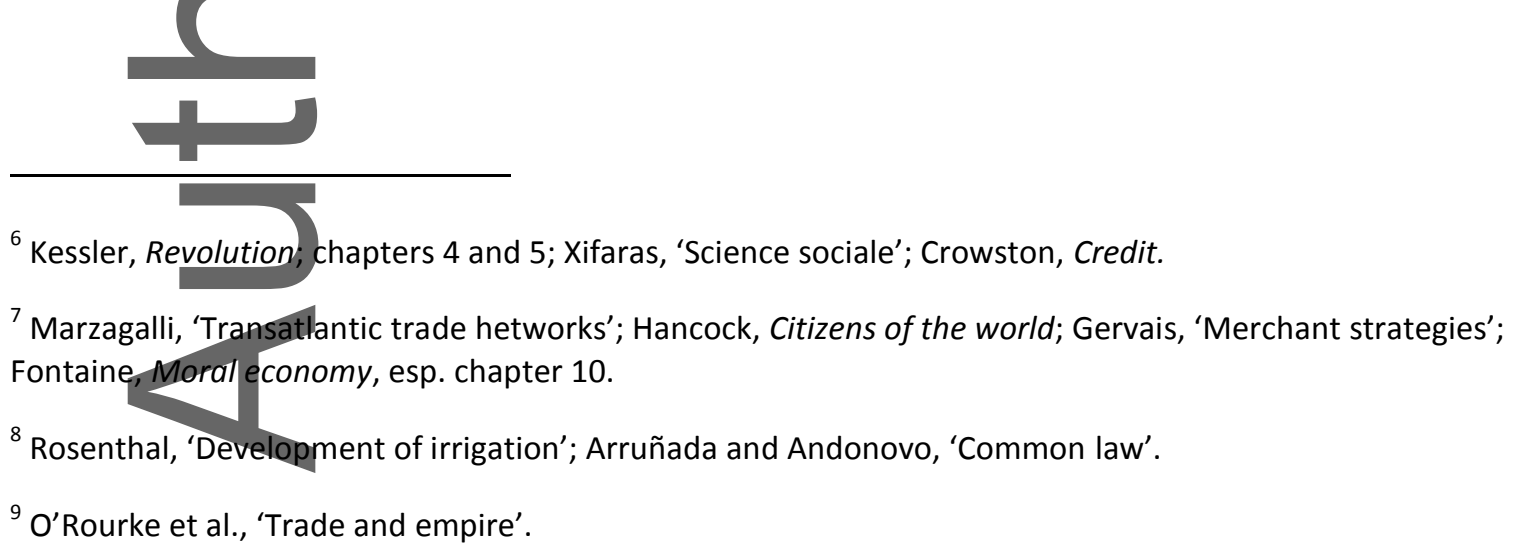

This article is protected by copyright. All rights reserved. 
standard modernization narrative holds true, it should be easily observable in France over this period.

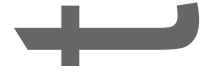

In reaching new markets, merchants had to overcome, in Braudel's words, 'distance, the first enemy'. ${ }^{10}$ Representation furnished a means both to conduct transactions at a distance and to support the geographically expanding structure of commerce. Along with business associations, sea loans, insurance, and bills of exchange, powers of attorney were part of the menu of contractual choices that offered merchants a device to span space, scale, and scope.

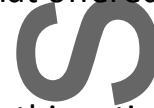

In this article, we empirically test whether agency relationships became more impersonal in France by analyzing power-of-attorney contracts that tied together principals and their proxies. To this effect, we use over 2,800 notarized proxy forms, covering four large French commercial cities at three different points in time $-1751,1800$, and 1851 - to build a novel dataset containing information on the identities of principals and proxies, their relationships, and the terms of these delegation contracts. These contracts capture a wide variety of agency relations; e.g., legal representation, debt recovery, inheritance proceedings, sale of merchandise, management of business and assets. We combine evidence from both cross-section and time-series dimensions of our data to investigate which types of proxy were chosen for each type of task across several geographical markets, and when and how these contractual practices responded to the macro events of the turn of the century. This allows us to revise the modernization narrative with respect to both the characterization and the timing of the supposed drastic shift.

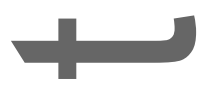

Our fine-grained description of the general features of powers of attorney unveils a diversity of relational bases for cooperation that escapes the personal vs. anonymous dichotomy. Consistent with our findings, some scholars have cast doubt on the radical opposition between two ideal-types

\footnotetext{
${ }^{10}$ Braudel, Mediterranean, title of Part 2, p. 355.
}

This article is protected by copyright. All rights reserved. 
of economic relationships. ${ }^{11}$ Accordingly, we have devised more nuanced hypotheses of the transformations leading to the birth of modernity, which we test in addition to the main narrative described above. ${ }^{12}$ Inherited relationships were not simply displaced by anonymous exchanges based solely on the quality or price of goods. ${ }^{13}$ Alternative and complementary mechanisms were at play: (1) homophily, (2) relational chains, and (3) relations rooted in division of labour and professionalization

First, relationships based on a shared social status or occupation, or, more generally, the preference for persons similar to oneself as partners ('homophily'), do not have to be restricted to inherited ties. Other shared attributes can likewise signal trustworthiness. In our period, Trivellato insisted on the shared language of long-distance merchants as such a signal. ${ }^{14}$ The status of such homophilyin modernization narratives is unclear. Homophily based on acquired skills or status could have replaced inherited ties, allowing markets to grow; or it could in turn have declined, as more dissimilar partners in turn opened new opportunities. The relational chain is the second type of Part mechanism that economic sociologists as well as business historians have recognized; for example,

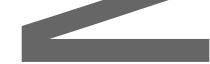

${ }^{11}$ Sociologist Granovetter, 'Economic action', for example, questioned what he termed the 'over-socialized' and 'under-socialized' fictions of human behaviour.

${ }^{12}$ We developed our hypotheses in the context of a wider research project that uses two additional sets of sources to examine the narrative of a supposedly decreasing embeddedness of commercial relationships from the eighteenth to the nineteenth centuries. Along with powers of attorney, we investigate in a panel data of important merchant houses: (1) the first letters in each merchant correspondence ('lettres d'entrée en relation') so as to understand why some of the first letters attempting to start a relationship were answered while others were not; and (2) the use of printed circulars ('lettres circulaires'), a device that could be considered, at first glance, less personal than the classical merchant correspondence. Those two sources only inform us about relationships among merchants (large-scale merchants, merchant-bankers), whereas powers of attorney allow us to compare merchants with other professional groups. For the first results from these other sources, see Bartolomei et al., 'L'encastrement'.

${ }^{13}$ Uzzi, 'Social structure', calls those 'arm's-length' market relationships.

${ }^{14}$ Trivellato, Familiarity, shows that mastering the right way to write a business letter, for instance, could foster transactions between trans-oceanic partners with different faiths and native languages. Being a merchant was something that could be learned (during our period, increasing numbers of merchants' handbooks taught correspondence) and, once learnt, could be considered a sign of trustworthiness.

This article is protected by copyright. All rights reserved. 
recommendations have figured prominently in accounts of long-distance trade. A relational chain involves at least three actors, and it allows expansion beyond inherited ties. ${ }^{15}$ In our case, it means (J)

that principals chose proxies with whom they were not personally acquainted, but whom others had recommended. Hoffman et al. investigate the role of notaries in forging ultimately anonymous links in French credit markets. ${ }^{16}$ Repeated relationships between the notary and his client involved the exchange of privileged information which the notary drew upon to match unrelated parties. Finally, sociological accounts of modernization imply that relationships were progressively dictated by division of labour and the emergence of professional agents. ${ }^{17}$ Following Chandler, business historians often endorse this narrative. ${ }^{18}$ All in all, these more nuanced accounts point not to disembeddedness but to an evolution and a reconfiguration of social ties. In addition to testing for the 'stronger version' of the modernity postulate, we test, in the following sections, for the prevalence and evolution of each of these transformations.

The remainder of the article is organized as follows. In Section I, we present our data and sampling strategy. In Section II, we address the modernization narrative in its boldest form by testing for a drastic shift over time in personal relationships between principals and proxies. In the same section, we explore our uniquely rich dataset to reveal general patterns on the uses of powers of attorney. We then turn to alternative mechanisms supporting relationships based on homophily (Section III), relational chains (Section IV), and the professionalization of agents (Section V). We discuss our esults and avenues for future research in Section VI.

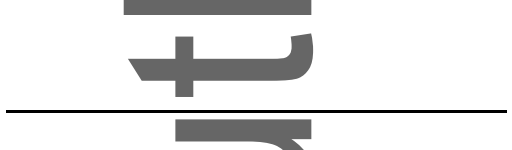

\footnotetext{
${ }^{15}$ Grossetti et al., 'Stydying relational chains'.

${ }^{16}$ Hoffman et al, Priceless markets.

${ }^{17}$ For Weber, Economy and society, organized professions, formal institutions, and anonymous markets supported one another (Ritzer, 'Professionalization').

${ }^{18}$ Chandler, Visible hand, p. 27.
}

This article is protected by copyright. All rights reserved. 
The extensive paper trail that powers of attorney (mandats) have left in early modern and modern archives testifies to their importance. ${ }^{19}$ Those proxy forms (procurations) are everywhere in the French notarial records and present in most Continental European and U.S. archives. ${ }^{20}$ For the year of 1851, proxy forms represent 14 per cent of all Parisian notarial records (c.60,060 acts in total). ${ }^{21}$

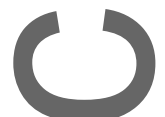

Despite their centrality for the expansion of trade, their ubiquity in managing many aspects of everyday economic life, and the fact that these contracts therefore had an important economic impact, 'scholars usually skip them [powers of attorney] as mere preliminaries or accessories to the more complex and specific contracts' ${ }^{22}$ It is, in fact, surprising that discussions in the economics literature of principal-agent relationships have not fostered more interest in such contracts, as powers of attorney were the main, if not the only, legal vehicle for such relationships in the eighteenth and nineteenth centuries. Even more puzzling is the absence of the mention of powers of

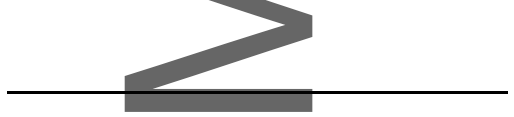

${ }^{19}$ We use 'proxy form' to refer to the piece of paper recording the contract, and 'power of attorney' to refer to the contract itself, which may or may not have been recorded in writing.

${ }^{20}$ Antunes and Riberio da Silva, 'Cross-cultural entrepreneurship' (Amsterdam). Trivellato, Familiarity (several European countries). For the U.S.A.: Acker, Deeds; Smith and Owsley, eds., Papers; Price, 'Manuscript sources'.

${ }^{21}$ For Paris in 1751, the share was $11 \%$ (on c.59,730 acts). For Marseilles in 1751, our estimate is around $17 \%$ (on c.11,280 acts). In Livorno in 1751 and 1761, Francesca Trivellato (personal communication, 4 July 2017) found $18 \%$ and $20 \%$ of proxy forms, respectively.

${ }^{22}$ Lopez, 'Proxy in medieval trade', p. 189. We found only a few exceptions to this scholarly neglect. In a pioneering paper that attracted no followers, the French specialist of notarial records, Jean-Pierre Poisson, advocated for a systematic study of powers of attorney as the only way to quantify trust. Recently, a series of papers on both sides of the Atlantic treated them as evidence of trust put in wives by husbands traveling abroad. Poisson, 'Sociologie des actes de procuration'; Sturtz, 'Virginia women'; Dufournaud \& Michon, 'Les femmes et le commerce'; Cyr, 'L'activité économique des femmes'; Grenier and Ferland, 'Procurations et pouvoir féminin'; Palmer, 'Women and contracts'. Lozano Salado, 'Dos siglos', traces the evolution of commerciat activity in Cadix through powers of attorney. Mostly ignoring one another, these papers generally deal with a very small sample of powers of attorney. The only systematic study, comparable in scope and sample size to ours but restricted to a rural region and purely descriptive, is that by Molina Jiménez in 'Informe sobre las cartas poder' and 'Solidaridades, conflictos y derechos'.

This article is protected by copyright. All rights reserved. 
attorney in debates about trust in the economic literature. ${ }^{23}$ In contrast, legal scholarship in fiduciary law, a branch of law that deals with agency costs plaguing contracts such as powers of attorney, often portrays powers of attorney as the archetype of interpersonal trust but has shown no interest in their historical uses.

Our article fills this gap in the literature by providing the first systematic descriptive account of the uses of powers of attorney, unveiling which types of proxy were chosen for each type of task over time and in several geographical markets. We deem it likely that many of the patterns that we find hold for other times and places, and could thus offer a basis for comparative research. Additionally, in order to test the modernization narrative, we compare how the relational bases in agency contracts evolved over time in three samples: 1751, 1800, and 1851 . The years 1751 and 1851 were unexceptional politically and economically (there was no revolution, war harshly impacting trade, large wave of bankruptcies, etc.). Moreover, they coincide with the dates of a digital database of all Parisian notarial records (ARNO), which provided information useful to selecting the notaries suitable to our study. The year 1851 is situated after major changes in transportation due to the creation of canals and railways in the 1820s-40s, but long before the telegraph began to be routinely used for commercial purposes. Our use of the year 1800 as a midway check allows us to observe the initial effects of the legal reforms that the French Revolution instantiated. In the context of revolutionary and imperial wars, 1800 was relatively uneventful.

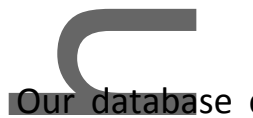
covers four French cities: Paris, Lyons, Marseilles, and Lille. Each one had prominent merchants in our period and was tied to different industries and important commercial
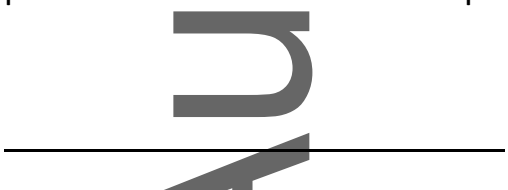

${ }^{23}$ For a critical survey of the trust literature, see Guinnane, 'Trust'. Like him, we consider that the concept of trust does not add much to our understanding of delegation, as it is often loosely defined or refers to something we cannot observe. We do not assume that a power of attorney is just the legal vehicle for preexisting trust or the expression of preexisting personal commitments.

This article is protected by copyright. All rights reserved. 
activities in different regions of the world. ${ }^{24}$ Paris, Lyons, and Marseilles were the largest cities by population and the most important commercial centers in France in the eighteenth and nineteenth centuries. Lille was the only major French city with an experience of industrial growth and rural exodus similar to that apprehended by the British. ${ }^{25}$ We chose three notaries in each city, for each year, and collected all the proxy forms registered by those notaries in those years, rather than using a random sample of all notarial records. This latter solution would not have been very practical (except for Paris in 1751 and 1851) due to the lack of a consolidated list of all notarial records (dozens of notaries worked in each city).

We selected those notaries who had the greatest number of merchants among their clientele (see Online Appendix for details). We intentionally biased our data collection in favor of merchants, as they often play the role of protagonists in the storyline of the rise of a commercial, impersonal society. Note that by oversampling merchants, who in any case under this account would be more prone to impersonal relationships, we make it easier to find the radical shift predicted by the dominant narrative of modernity.

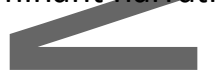

We collected in total 2,831 proxy forms ('full sample'). Notarized proxy forms could record the identity of the proxy (72 per cent of the forms did), could be blank ( 21 per cent) - that is, no name or function was given for the proxy, just a blank space - or could have originally been blank and filled in later (7 per cent). For each proxy form, we coded its length (85 per cent were two pages or fewer); the main object of the agency contract; and variables describing the identities and gender of both the principal and the proxy (one quarter of the principals and 10 per cent of the known proxies were female) and, if recorded, their occupation or social status, their addresses, and the

\footnotetext{
${ }^{24}$ See for example, Bergeron, Banquiers; Chassagne, Veuve Guerin et fils; Carrière, Négociants marseillais; Hirsch, Entreprise et institution.

${ }^{25}$ Bairoch, Batou, and Chèvre, Population des villes européennes.
}

This article is protected by copyright. All rights reserved. 
relationship between them. (See descriptive statistics on all our variables in Table 1 of the Online Appendix.) In addition, for 870 randomly selected forms ('reduced sample'), our database records each of specific subtasks the proxy was authorized to perform for the principal, along with a dozen variables referring to the existence of diverse restrictive or discretionary clauses.

In spite of legal and economic mutations between 1751 and 1851, as Table 1 shows, the types of principals and tasks in our samples did not change much over time. In each period, one quarter to one third of the proxies were supposed to recover debts or other sums owed; the same share of contracts had to do with managing estates, inheritance proceedings, or doing everything for the principal; 20 to 25 per cent of forms delegated the task of selling annuities or collecting interest, except in 1800, when the market for annuities had collapsed. Overall, one quarter of principals were merchants (more for debt recovery); approximately 15 per cent were in other commercial occupations (bankers, artisans, skilled workers, etc.); one quarter of the occupations were unknown; and the rest were lawyers, civil servants, 'propertied persons', clergy members, etc.. As the use of

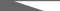
notarized powers of attorney changed very little over time, we have a good vantage point to observe evolutions in the choice of proxies and their relationship with principals.

A caveat to our sample is that a power of attorney could be granted, and considered as such in courts, without being notarized. It is, therefore, likely that the vast majority of powers of attorney did not survive - or even were never written, or written as such. An oral order, or the order to do something included in an ordinary letter, could be considered valid by a court, both before and after the French-Revolution. ${ }^{26}$ In addition, one way to make the contract more official while paying less than a notarial fee was to have it registered (acte sous seing privé), which left few usable traces in

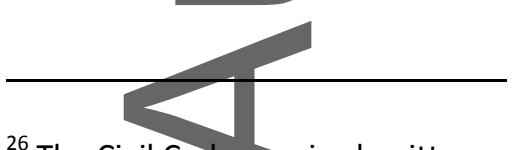

\footnotetext{
${ }^{26}$ The Civil Code required written proof for powers of attorney whose subject matter exceeded the value of 150FF. If the object was commercial, witnesses could, however, substitute the written proof, independently of the value (Dalloz and Dalloz, 'Mandat', p. 682).
}

This article is protected by copyright. All rights reserved. 
the archives. ${ }^{27}$ Further, it could be argued that, ceteris paribus, the closer the preexisting relationship, the less the power would need to be notarized. This could be true because social norms would make formalization less necessary (by ensuring that no dispute would occur, or that disputes would be dealt with inside the family) or for legal reasons. ${ }^{28}$ The fact that we find as high as 25 per cent of notarized forms given to kin, however, indicates a demand for formalization of even the most embedded relationships. Those contracts were, in fact, strikingly similar to all the others in terms of length and final clause.

Drawing more complete, official contracts could indeed have its virtues. The proxy might have needed to prove to third parties her legitimacy to conclude a binding deal. For women, minors, or foreigners, formalized powers of attorney acted as a bulwark for the legal rights of those holding the proxy rather than as a safeguard for those giving the proxy. Finally, it is likely that powers of attorney were notarized if high stakes were involved (such as general powers to manage the properties of a person), or because the parties anticipated that they might have to go to court. Whereas non-notarized and even unwritten contracts could be admitted as evidence, the many ongoing jurisprudential debates, both before and after the Revolution, suggest that leaving judges to apply default rules could be a risky strategy. ${ }^{29}$ Thus, a notarized proxy form does not signify an especially high level of trust between the parties but could, in some cases, conceivably indicate some

\footnotetext{
${ }^{27}$ The notarial fees to write a proxy form were never officially standardized, but the total expenses incurred for a notarized form in Paris seems to have been about 2 to 2.5 livres before the Revolution and 17 to $25 \mathrm{FF}$ after the Revolution (in other cities, the sums were a bit lower). This amounts to about 10 days of work for an unskilled male worker. Written, registered, but non-notarized proxy forms (actes sous seing privé) only were charged a registration tax of about 10 sols, then a little more than 1FF (half a day of work). The archives have traces of their registration, but they very often give only the date and the names of the parties. On notarial fees, Amiaud, Le tarif général; Mourlon and Jeannest-Saint-Hilaire, Formulaire général.

${ }^{28}$ For example, Art. 1432 of the Civil Code explicitly stated that each spouse tacitly had the power to manage the other's property. In the eighteenth century, jurisprudence recognized that a wife did not need a written proxy from her husband to buy merchandise (Crowston, Credit).

${ }^{29}$ Pothier, 'Traité du contrat de mandat'; Troplong, Le droit civil expliqué; Dalloz and Dalloz, 'Mandat'; Xifaras, 'Science sociale'; and Pfister, 'Un contrat en quête d'identité'.
}

This article is protected by copyright. All rights reserved. 
measure of distrust that had to be mitigated by reliance on the legal system as a credible threat of sanction.

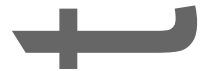

Yet, the study of clauses in our sample qualifies the idea that the added formalization would have primarily been used to prevent abuse by the proxy. On the contrary, the most detailed a

contracts gave the proxy more discretion. Pothier, writing in the 1760 s, discussed the interpretation of prices given in powers of attorney and insisted that the principal would ultimately have to agree to those prices. ${ }^{30}$ However, almost none of our contracts mention specific prices, and many explicitly state, in their final clause, that the principal promises to 'agree to the terms determined by the proxy' ('avoir le tout pour agréable') or, in 35 cases, to ratify all the actions of the proxy. ${ }^{31}$ Only 6 per cent of our contracts include any kind of restriction on the proxy's discretion, for example, discussing with the principal before making some decisions; or specific parameters on a certain task to be executed, such as the length of leases the proxy must decide on. On the contrary, many contracts use long clauses that emphasize the proxy's discretion; as an instance, the proxy can sign a settlement in a bankruptcy proceeding, even at a loss. They enumerate all the tasks that the proxy was authorized to perform as a consequence of the main task. For example, 45 per cent of the contracts mention the possibility of going to court; whereas, representation in court was the main object of only 4 per cent of our proxy forms. In addition, final clauses often add the idea that the proxy should do 'as the circumstances will dictate' ('ce que les circonstances exigeront'), 'what will

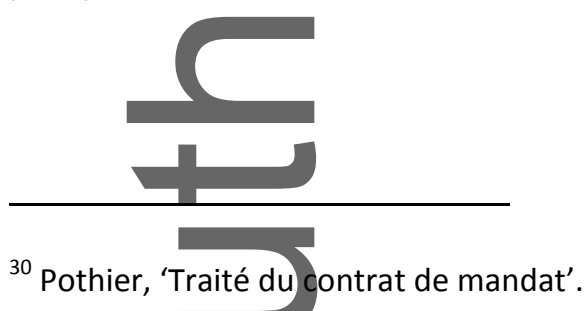

${ }^{31}$ Numbers and frequencies in this paragraph refer to our reduced sample. The clause was used by Londoners, in 1851, to have the Parisian banker Ferrère-Laffitte recover annuities for them in Paris (e.g., Archives Nationales, MC/ET/X/1216, 2 Feb. 1851: deposit of proxy form drawn in London, 24 Jan. 1851), as well as by an unmarried Marseillaise cook, Marie Sophie Franchette Cornut, in the same year, who gave blank powers to deal with her father's inheritance; he was a blacksmith who had died in Switzerland (Archives départementales des Bouches-du-Rhône, 364E640, 7 April 1851).

This article is protected by copyright. All rights reserved. 
be useful' ('tout ce qui sera utile'), 'and generally do whatever is necessary' ('et généralement faire le nécessaire').

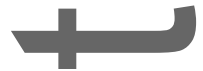

Althought is conceivable that we are working with a small, non-representative subsample of the contracts that a lawyer would consider as powers of attorney, the vast quantities of notarized powers of attorney are significant enough to warrant attention. In addition, the discussion above suggests that self-selection in notarizing the proxy form is unlikely to be an issue. Most importantly, since we are interested in changes over time in the fraction of personal versus impersonal relationships, a potential bias would only arise if the probabilities to formalize personal and impersonal relationships changed differentially over time. We are not aware of events that would have altered the demand for formalization differentially for personal and impersonal relationships over time.

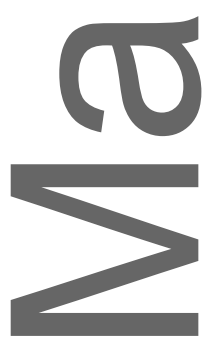

\section{II}

The narrative of modernization would imply that over time principals relied less and less on proxies with whom they had close ties, especially members of their family. In addition to testing this hypothesis, this section casts light on other interesting patterns regarding the uses of powers of attorney by gender and occupation of the principal, and how the task to be performed influenced the choice of proxies.

Having surveyed a large quantity of notarized proxy forms, we are confident that the archetypical types of personal relationships were exhaustively recorded in the source: kinship ties were found in 17 per cent of cases, including 5 per cent of spouses, and other explicit ties in 2 per This article is protected by copyright. All rights reserved. 
cent of cases. ${ }^{32}$ In addition, we deduced from their addresses that some parties lived in the same building or on the same street, which we considered as a likely personal tie between neighbours (found in 16 cases, or 0,8 per cent of forms). This leaves the vast majority of cases without any recorded preexisting relationship between the parties. Even if we exclude blank forms, which we will discuss in Section IV, 80 per cent of powers did not contain any information on the relationship between the parties. This does not mean that the interactions represented by these 80 per cent were completely anonymous. Apart from occupational homophily or relational chains, which we discuss in the following sections, the obvious case is that of 'friendship', the ideal-type used by lawyers to characterize powers of attorney. The parties and the notaries did not, however, use the vocabulary- of friendship in any way, be it purely rhetorical or not, in the contracts; they did not give any hints, either, about shared citizenship, religion, or any other basis for communitarian solidarity.

A preliminary analysis of the evolution of the fraction of proxies given to kin and other explicitly related persons, depicted in Table 2, reveals that the differences between 1751 and 1851 are not striking. Interestingly, Poisson found a similar share of proxy forms given to kin (24 per cent, including 11 per cent between spouses) in Parisian records of the 1960s, despite their being quite different from ours in terms of the tasks to be performed. There were no debt recoveries, inheritance proceedings, or management of estates; but more sales and loans existed than in our period. $^{33}$

In order to more rigorously test whether relationships between principals and proxies in the notarized contracts became more impersonal from the eighteenth to the nineteenth centuries, we employ the following simple specification:

\footnotetext{
2

32 Percentages calculated on non-blank forms. Our 41 'other explicit ties' include 16 employees of the principal, 7 associates, 3 colleagues (e.g., priests in the same congregation), and 15 miscellaneous cases.

${ }^{33}$ Poisson, 'Sociologie des actes de procuration'.
}

This article is protected by copyright. All rights reserved. 


$$
\text { Personal }_{i}=\beta_{0}+\beta_{1} X_{i}+\gamma_{1800} t_{1800}+\gamma_{1851} t_{1851}+C+\varepsilon_{i}
$$

where Personal $_{i}$ denotes the binary outcome of interest, in this case, whether in the proxy form $i$ a personal tie (defined as above; therefore, often a family tie) existed between the principal and her proxy; $X_{i}$ is a vector of characteristics such as the main object of the agency contract, the notary's location, the principal's occupation, the number of principals listed and their gender; $t_{1800}=1$ if year $=1800$, zero otherwise and $t_{1851}=1$ if year $=1851$, zero otherwise (1751 is the reference year) ; C are city fixed effects; and $\varepsilon_{i}$ is the idiosyncratic error term. These underlying variables are defined in Table 1 of the Ontine Appendix. The model is estimated using a logistic regression and the sample is restricted to non-blank powers; i.e., to those powers of attorney for which the principals directly chose the proxies, as opposed to 'blank' or 'filled-in blank' powers in which another person, probably a notary in many cases, chose a proxy on behalf of the principal. ${ }^{34}$

\section{The modernization thesis predicts that $\gamma_{t}<0$ and is decreasing in $\mathrm{t}$ (when 1751 is the} reference category). As Table 3, column 1 shows, this hypothesis is rejected in our data: both cohort coefficients are insignificant, which suggests no changes over time in principals' reliance on agents with personal ties. Furthermore, this result is robust to alternative specifications. ${ }^{35}$ First, redefining the dependent variable more conservatively to consider personal links as only those with family ties does not change the results. Second, it is theoretically possible that the aggregate results might be masking subtler patterns of depersonalization led by differential trends by city, object of the power of attorney, or the principal's occupation. For example, Paris, as the more 'modern' city, might have

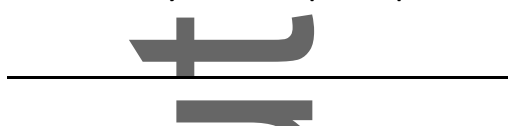

\footnotetext{
${ }^{34}$ As discussed in Section IV, principals may choose to grant a power of attorney through a blank or a nonblank form. Conditional on the principal's choice of a non-blank form, the principal decides on the identity of the proxy. In contrast, with a blank form the ultimate choice of the proxy lies outside of the principal's control (with a notary for instance). Using the full sample to study the personal versus non-personal choice would therefore conflate the principal's and the notary's choices. In Section IV we focus on the choice between blank and non-blank as the outcome variable.

${ }^{35}$ Results available upon request.
}

This article is protected by copyright. All rights reserved. 
had a head start in modernizing, commercial matters might more easily have been handled by strangers, and merchants were often regarded as more prone to impersonal relationships. To test of year with city, object, or principal's occupation. All cohort coefficients and most interaction coefficients are insignificant, which rules out different evolutionary paths by city, by type of object, and by type of occupation.

Table 3 column 1 also reveals interesting patterns vis-à-vis powers of attorney in general. Other things being equal, female principals compared to male ones tended to engage proxies with personal links. The recent literature on powers of attorney given to wives by their husbands notwithstanding, the reverse situation was as frequent. Merchant principals were more prone, all other things being equal, to choose strangers as proxies, seemingly confirming contemporary suspicions that they were at the vanguard of anonymizing the delegation of power.

Compared to the reference category - which includes commercial operations such as (mostly) the sale of merchandise or ships, the management of bankruptcies, and the winding up of businesses - principals tended to choose proxies with personal ties less often for other limited, specialized tasks. Such tasks included management of annuities and lawsuits; only 6 per cent of nonblank proxies dealing with annuities were kin, and 12 per cent of attorneys-at-law. Conversely, proxies with personal ties were more likely to be chosen to exercise general powers, which entitled the proxy to do everything in the principal's name, or to perform such tasks as the management of inheritance proceedings, of a company, of land and buildings. Those tasks were mostly noncommercial; but, more importantly, they were complex and consequential. Here, the intuitive idea that they would not be delegated to an unknown person often holds. Spouses received 33 per cent of the 130 general powers of attorney, and 30 per cent were given to other kin (but 3 are blank). Out of 82 non-blank proxy forms to manage a company, 31 were given inside the family, 4

This article is protected by copyright. All rights reserved. 
were given to neighbours, 3 to an associate, and 6 to an employee: this is the one task for which 'other ties' played an important role. Anecdotal evidence from a study of printed circulars from the nineteenth century hints that such powers of attorney were one step in commercial careers, used to further integrate young relatives and sometimes long-serving employees in a company before making them full partners. ${ }^{36}$

Our evidence is thus consistent with no depersonalization per se, in the sense of principals' consciously being more likely, over time, to choose unrelated parties to the detriment of kin or other close acquaintances.

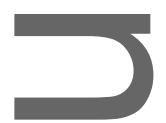

Proxy forms do not inform us about the embeddedness of commercial relationships in friendship, religious, or ethnic communities. They allow us, however, to test the version of the homophily hypothesis discussed in the introduction: does the mere fact of being a merchant matter to fellow merchants when it comes to choosing a proxy?

The words marchand, négociant, and commissionnaire, which we have used to define the category 'merchant', were still often used, in the first half of the nineteenth century, with Old Regime sociat statuses in mind. That is, they denoted wholesale operations and some degree of recognition by fellow merchants as being part of a local elite. ${ }^{37}$ An interesting anecdotal case hints that those self-identifying as merchants could be considered, by fellow merchants, better proxies

\footnotetext{
$\longrightarrow$

${ }^{36}$ See, for example, abrother and employee (Centre d'archives du monde du travail [henceforth CAMT], 69AQ/3, sent to Foache from Le Havre, 1 Jan. 1824); a brother-in-law (Archives municipales de Marseille, Fonds Roux,LIX-164, sent from Bordeaux, 1 June 1816); a son (CAMT, Le Havre, 1 July 1826); long-time employees (CAMT, Le Havre, 28 Aug. 1817, 1 March 1824, 1 Jan. 1828, 10 April 1830) promoted to proxy in various companies, sometimes explicitly as a 'testimony of our trust'; another son promoted from proxy to partner (CAMT, Le Havre, 1 Jan. 1827); and a long-time proxy of the father, then of his son, finally becoming a partner (CAMT, Le Havre, 1 June 1814).

${ }^{37}$ Carrière, Négociants marseillais.
}

This article is protected by copyright. All rights reserved. 
than others. In a related study of printed circulars, we found a former merchant, a certain Bruguière, advertising for his new company, which offered services of representation in courts and, more broadly, before the authorities. Bruguière used the mutual recognition among merchants to promote his new business and stated that a former merchant would provide better services than any other person. ${ }^{38}$ This rhetoric points to the signalling power of the label 'merchant' among peers.

Since oun dataset records the occupation of principals and proxies, we can test for the presence and evolution over time of relationships based on occupational homophily. In Table 3 column 2, we estimate specification (1) with a set of interactions of year with principal's occupation and using as a dependent variable a binary outcome indicating whether the principal and her proxy shared the same occupation, defined in broad categories. ${ }^{39}$ The regression results reveal that merchants were more likely than those in other categories to choose a proxy in their own occupation (ceteris paribus, i.e., not just to perform commercial tasks). However, the interaction terms show that this homophily among merchants decreased between 1751 and 1851 (Figure 1 in the online appendix visually sums up the results of the interaction regression). While merchants remained more likely than principals in other categories to choose a proxy in their own occupation, this decrease made them less specific. We may here be capturing an effect of the revolutionary abolition of statutory privileges as well as of simultaneous economic and social changes, including

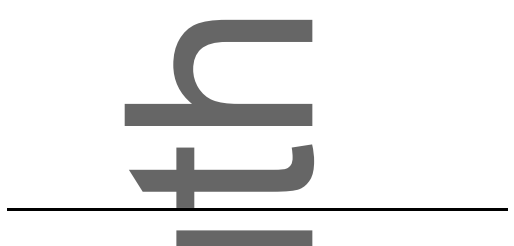

\footnotetext{
${ }^{38}$ Bruguière's case also exemplifies the prevalence of professional proxies and the use of relational chains. He certainly had to use licensed attorneys to go to court, but his skill as a professional proxy (he stated that this sort of business required 'full-time dedication') knowledgeable about the needs of merchants would be to find the best attorneys. Archives municipales de Lyon, Fonds Veuve Guérin, 4J331, sent by Bruguière aîné, 'agent de commerce' in Marseilles, 1 May 1809.

${ }^{39}$ Merchant; financial occupation; employee of merchant; manufacturer, artisan, shopkeeper or skilled worker; lawyer; civil servant; 'propertied person'; other.
}

This article is protected by copyright. All rights reserved. 
specialization, textbooks' and printed directories' lowering barriers to entry, that cast doubt on the qualities previously associated with the merchant category and on the boundaries of that category. ${ }^{40}$

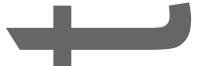

How can we distinguish between a match based on professional expertise and one based on status or membership to a group? That is, when we see a principal merchant choosing a merchant as .

a proxy, is it due to a mutual recognition of belonging to a group ('status homophily') or due to the merchant proxy's special abilities and skills ('preference for merchants' skills')? Controlling for the task to be performed gives us a partial answer: what we observe here is not only the choice of merchants to recover debts, settle accounts, or manage businesses. Merchants in our sample gave 36 of their non-blank general powers or powers to deal with inheritance, land, or family to fellow merchants, including 26 to unrelated merchants. This is suggestive of homophily, although we cannot rule out that some of those unrelated merchants were social acquaintances, living in the same neighbourhood or meeting at the stock exchange, for example; whereas, others were perhaps generally deemed trustworthy as merchants.

An alternative analytical strategy builds on the fact that merchant proxies might have possessed special skills which were valued by other groups as well. Table 3 , column 3 shows the results of a regression that estimates specification (1) with a dependent variable indicating whether the proxy is a merchant (17 per cent of non-blank forms), and includes a set of interactions of year with principal's occupation, broadly defined. We find that merchants as principals are more likely to choose merchant proxies than principals in noncommercial occupations; whereas, the coefficient for other commercial occupations (bankers, manufacturers, employees of merchants, artisans, etc.) is $\longrightarrow$

${ }^{40}$ Deschanel, 'Que vaut un négociant?', who studied the fates of merchants and of the word 'négociant' during and after the French Revolution, similarly concludes that the category kept its meaning but witnessed important transformation. Bartolomei et al., 'L'encastrement', on the basis of merchant correspondences, find that established houses still relatively avoided outsiders, especially specialized traders who would not selfdescribe as 'merchants'.

This article is protected by copyright. All rights reserved. 
not significant. Under the assumptions that principals of all groups have equal access to merchant proxies, and that merchant proxies' skills are equally valuable to principals of all groups, this result indicates a preference for a social group and not simply for the skills associated with the agent performing commercial transactions.

口

However, starting in 1751 the share of merchants among proxies continuously decreased over time among all groups. According to the interaction terms, this decrease was less pronounced among merchants principals compared to other groups. Between 1800 and 1851, all other things being equal, the share of merchant proxies among principals of other groups decreased at a faster pace than among merchant principals. This analysis would point generally toward merchants' remaining a rather distinct social group but being less often entrusted as proxies with tasks that were not strictly commercial - perhaps as a product of a growing division of labour. Our results here go in the direction expected by more nuanced modernization narratives but do not indicate radical change: homophily does not decrease for other occupations, and that between merchants remains high.
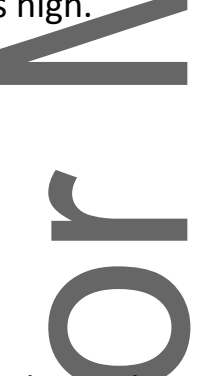

\section{IV}

The evidence found so far disposes us to dismiss the modernization thesis in its radical form, which postulates a shift from an ideal-type to another. Principals did not display an increase over time in their preference for strangers, and merchant homophily did not disappear. Personal ties and shared status were not, however, the only relational basis principals could resort to. In this section we take up the use of blank forms, which indicate an arguably more important change in the period: the increasing use of relational chains to find proxies. Such change is also evidenced by the frequent use of substitution clauses, in non-blank as well as in blank forms.

This article is protected by copyright. All rights reserved. 
In blank forms, no name or occupation was given for the proxy, just a blank space. Among our notarized proxy forms, 19 per cent were blank in 1751; 20 per cent in 1800; and 24 per cent in 1851. 8 per cent in 1751, 6 per cent in 1800 and 7 per cent in 1851 were originally blank and filled in later: the name, and often the proxy's occupation and address, were written in a different handwriting. Two thirds of our filled-in blank proxy forms are 'deposits': the proxy filled in his name, then had his notary record the form. Nineteenth-century lawyers made little or no mention of such a practice. Interestingly, a similar share of blank forms appeared in notarial records of the $1960 \mathrm{~s}^{41}$

Blank forms were, as one might expect, more often used for tasks such as debt recovery and going to court ( 35 and 36 per cent of blank forms) than for other tasks such as managing a company (12 per cent). To better assess change in the frequency of the use of blanks forms over time, we estimate (1) by defining as a dependent variable a binary outcome that takes a value equal to 1 if the proxy form is blank or filled-in blank; 0 , otherwise. The regression includes a set of interactions of year with principal's occupation, broadly defined. The 1851 cohort coefficient is significant and positive, indicating an increase in blank forms compared to 1751 (Table 4, column 1). Ceteris paribus, merchants were not more likely than other groups to give a blank power of attorney, but the interaction terms reveal more nuanced patterns. Compared to other groups, merchants already gave more blank powers in 1800 . This might mean that merchants were pioneers in this practice in 1800 , but by 1851 all the other groups had followed; and there is no difference among groups in the probability of giving a blank power of attorney.

Why would principals use blank forms, and was this choice a move toward more anonymity in delegation relations? The likelihood is that, in many cases, the use of a blank form was in some way related to the place in which the task was to be performed - something that we found ${ }^{41}$ Poisson, 'Sociologie des actes de procuration'.

This article is protected by copyright. All rights reserved. 
surprisingly difficult to code because it is very seldom explicitly mentioned. Perhaps the principal did not know that place well, but it was where the deceased had lived or the debtor was currently located, and so on. Thus, it might have been useful to find a still-unknown proxy there, rather than to employ someone the principal knew but who was located in the wrong place. For example, JeanCharles Galhaut, a merchant in Amiens, head of the Galhaut \& Thibaut Company, sought to recover 2,000 FF (equivalent to the yearly wages of a clerk) from a Lyonnaise company for merchandise he had sold them and for which they had not paid. His blank proxy form for this task was recorded almost one year later, in Lyons, filled in with the name of a company, not a person, as proxy ('Bourget père et fils aîné de Lyon'). ${ }^{42}$

This example, along with many others, suggests that drawing a power could be just one step in such a chain, ultimately leading to the creation of a principal-proxy relation. This chain probably relied on recommendations, especially by notaries and possibly by other professionals, such as lawyers. Lawyers writing about powers of attorney commented on the growing trust clients put in their notaries. ${ }^{43}$ Such commentators were talking about notaries acting as proxies, though, not as intermediaries used to find proxies. The role of French notaries in the circulation of economic information and the matching of contract partners has already been well documented. ${ }^{44}$ Similarly to what the literature has shown about the search for credit partners, our principals could have trusted their notary to look for a proper proxy and provide him with the blank form, which the proxy would then fill in with his name and sometimes record with his own notary. When the task had to be performed in a distant place, the notary in that place could be used as an intermediary to find an

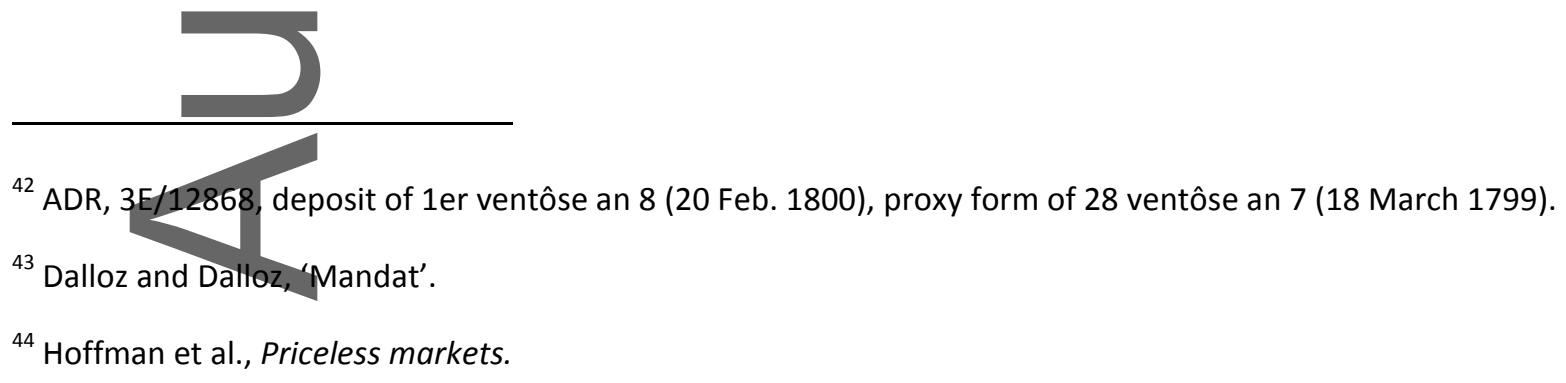

${ }^{44}$ Hoffman et al., Priceless markets.

This article is protected by copyright. All rights reserved. 
adequate proxy. In this sense, blank - and filled-in blank - forms indicate not anonymity but, rather, the role of relational chains.

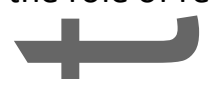

Moving from the relationship between the parties to the phrasing of the contracts, our data reveal an additional form and layer of delegation of authority creating relational chains. Substitution clauses, which have likewise not drawn scholarly attention, allowed the proxy to choose another proxy, who would perform all or some of the tasks included in the power of attorney. In the frequent case of a general substitution clause, the proxy could be only the first person in a chain of delegation of powers. Indeed, this clause was not a mere boilerplate, as we found 100 substitution contracts in our sample - that is, forms in which the first proxy transferred powers to a second one, without any explicit intervention of the principal. It is likely that many other substitutions occurred without being notarized, especially when they were partial and/or provisional.

These data undermine both the relational interpretation of powers of attorney as manifestations of trust that we find among nineteenth-century lawyers - a view that persists to our day - and the sharp divide built by contemporaries between powers given among equals and those given to professionals, as the former could be a first step toward the latter. A proxy form with a substitution clause could indicate that the principal entrusted the proxy not so much to perform tasks as to find reliable agents to do so.

Forty-seven per cent of the forms in our reduced sample include a final, general substitution clause. Around 23 per cent of all proxy forms (some of which might contain a final, general substitution clause) include a partial clause. They mention a specific task that could be performed by a person chosen by the proxy, who would often represent the principal in court or perform transactions for him/her at the stock exchange. These were tasks that only a licensed solicitor/attorney/barrister (avocat/avoué) or broker was authorized to perform. This suggests that 
principals might have chosen nonprofessionals as proxies for a general power of attorney -even if the general task to be performed included auxiliary tasks that would have to be subcontracted to professionals - and that many principals left the choice of these professionals to their proxy.

As Table 4 column 2 shows, substitution clauses were surprisingly ubiquitous in the sense -

that they were not significantly associated with specific types of principals (once again, merchants did not exhibit a particularly 'modern' behaviour) or strongly associated with specific tasks. Indeed, the only pattern that we found in general substitution clauses was a strong differentiation between cities, indicating local notarial custom. Partial substitution clauses, on the contrary (Table 4 column 3), were found everywhere in a similar proportion. This makes sense, as the skills and legal status of the proxy were unknown when the form was drafted: the proxy might need to provide legal representation or sell annuities and not be deemed able to do so. Partial substitution clauses, which thus can be read as indicators of the perceived need for specialization, interestingly were more frequent, ceteris paribus, in 1800 and 1851 than in 1751 . Although the evolution was not linear as there was a decrease between 1800 and 1851, this points in the general direction of professionalization.

Blank forms and partial substitution clauses were thus widely, increasingly, and often jointly used during our period. Modernization, in the case of proxy forms, seems to have very much relied on relational chains, with notaries playing key roles as brokers of recommendations as well as providers of legal devices.

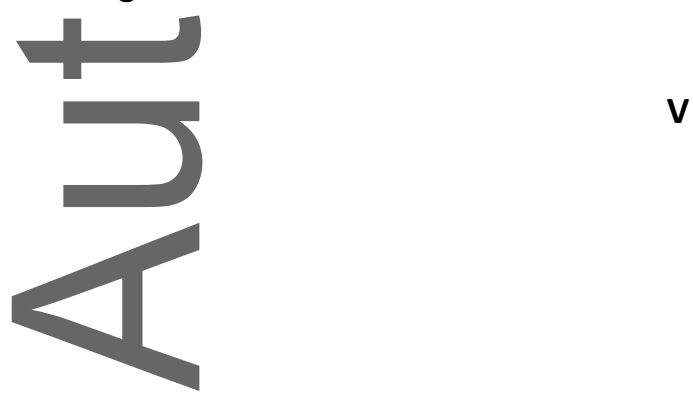

This article is protected by copyright. All rights reserved. 
Quite often, filled-in blank forms ended up with clerks of notaries as proxies. ${ }^{45}$ These clerks were clearly in a good position to be recommended to undecided principals. Some of them regularly (1) acted as proxies, performing a variety of tasks, receiving filled-in blanks as well as non-blank forms, seemingly making a reputation as specialists on the role of proxy. As in the case of partial substitution clauses, the empirical widespread presence of such frequent proxies is an indicator of a growing division of labour as well as of the importance of relational chains.

Conservative lawyers, as well as nineteenth-century writers generally, were very much concerned about this type of individual, whose only business was to manage the business of others. As their role as proxies would necessarily call for compensation beyond expenses, although the forms never explicitly stated this, they threatened the Roman definition of 'power of attorney' as a voluntarily accepted assignment from a friend. Often called 'agents d'affaires' ('business agents', with a negative connotation), they would perform all sorts of tasks as proxies or in other variously defined positions - for instance, as arbitrators for commercial courts, trustees in bankruptcies, etc. $^{46}$

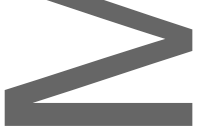

The growing division of labour at play in delegation, rather than a contract between similar friends, is apparent in the clauses of our reduced sample. Final clauses that explicitly stated that the proxy could do 'whatever the principal could have done if he or she had been present' ('tout ce que le constituant pourrait faire lui-même s'il était présent en personne'), or could have done 'in person', tended to disappear from cohort to cohort (Table 4, column 4). An alternative specification that has

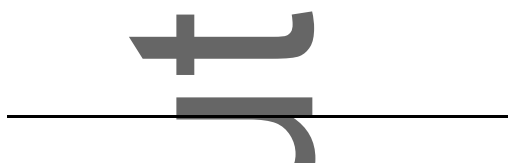

\footnotetext{
${ }^{45}$ This was the case for 24 filled-in blank forms, or $16 \%$ of those in which the occupation of the proxy was known, as compared to $4 \%$ of non-blank forms.

${ }^{46}$ Boigeol and Dezalay, 'De l'agent d'affaires au barreau'. Cheney, Cul de sac, documents the bad reputation of Creole managers acting as proxies of absentee owners of plantations; many such managers worked for multiple owners. Yates, 'Making metropolitan markets', discusses the birth of a new type of professional proxy: the real estate agent.
}

This article is protected by copyright. All rights reserved. 
' 1800 ' as the reference category confirms a significant decrease between 1800 and 1851 . Giving a power of attorney could more often be recognized as a way to get something done that one, despite T

being present, was not capable to do herself. This suggests that powers of attorney were used in the hiring of experts, or at least of proxies who had more knowledge or experience than the principal, in order to conduct specialized transactions. Consistent with this interpretation, the clause was more rarely found in contracts having to do with rent annuities and never in the contracts of frequent proxies, which we define as proxies that were found in at least four different proxy forms in our sample.

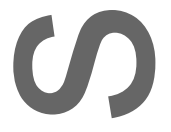

Having coded in our sample the identities of principals and proxies as well, we can identify frequent proxies and track their growing professionalization over time. We, in fact, found two different types of frequent proxies. The first type involved tasks that had historically been assigned to specific professionals long before our period. This was the case for attorneys-at-law, who did not need notarized proxy forms for each case - which explains why they do not figure prominently in our data - and for bankers and brokers dealing with rent annuities. Here, division of labour and professionalization were nothing new. For example, two brokers at the Lille stock exchange in 1851, Frédéric Tattet fils (a proxy in 79 separate contracts, or 38 per cent of our Lille sample for that year) and Joseph Jules Blerzy (20 contracts) used several different notaries, bringing their own standard proxy forms with them. All their contracts look the same, independently of which notary registered them. Some professionals who often acted as proxies, therefore, used notaries to certify their contracts but did not really need them to provide templates. They do not seem to have needed notaries to find clients, either; or, if they had needed them at some point, it was now sufficient to have repeated relations or direct recommendations by clients: 'Tattet' and 'Blerzy' appear on no filled-in blank form. We found no equivalent in our 1800 sample, when banks and the stock exchange were disorganized, but frequent proxies dealing with rent had already appeared in 1751 .

This article is protected by copyright. All rights reserved. 
For example, in our Parisian archives for 1751 , we found 12 non-blank forms and 4 filled-in forms given to Anne Marguerite de la Faye de Joyenval, the widow of a 'rent receiver' ('receveur des rentes') who obviously continued his business. In a regression not reported here but including the same covariates as in (1), we found no cohort effect on the use of such frequent proxies.

The second type of frequent proxy comes closer to the idea of a generalist professional proxy, or business agent. This time, it seems indeed to be a figure of the nineteenth century. To delimitate this group, we focus on proxies appearing at least 4 times in our sample and who do not deal with rents. Their main tasks were the management of estates or inheritance proceedings and debt recovery. We find 18 persons and 124 contracts, 98 of which were drawn up in 1851 . This represents 11 per cent of non-blank or filled-in blank forms for this cohort, as compared to 2 per cent in 1751 and 1800 . This effect holds in a multivariate regression (Table 4, column 5): the coefficient for 1851 indicates that principals were over 4 times more likely to use a generalist professional proxy than their predecessors were in 1751. Contrary to other commercial occupations, merchants were as equally likely as propertied persons or civil servants to use this type of proxy.

Honing in on frequent proxies makes it clear that the emergence of professional business agents did not necessarily imply anonymity, not only because principals relied on the proxies' names, which they might have found in directories, but also because recommendation played a role. Étienne Maurice Olivier, a notary's clerk, was a proxy in eight contracts in Lille in 1851. He held three non-blank and five filled-in blank forms. He could take advantage of his professional position to benefit from the brokerage of notaries (he used at least two separate notaries) and find clients in Paris, Tours, and Libourne (near Bordeaux) as well as in and around Lille. He sometimes was a broker himself rather than a genuine proxy, however: we also found a substitution contract in which he transferred the powers conferred to him by Antoine Louis Vallois, a 'former merchant and propertied man' of Wazemmes, near Lille, to Pierre Joseph Lecieux, another notary's clerk in Lille This article is protected by copyright. All rights reserved. 
whom we found as a proxy in two other contracts. ${ }^{47}$ The substitution does not give any information on the tasks to be performed; in other cases, Olivier was chosen to sell land and buildings, manage inheritances, and recover debts.

Joseph Darasse, a Parisian merchant, was a more specialized frequent proxy. He was chosen (1)

by 13 clients of the same notary; all but one were representatives of France abroad, such as consuls, interpreters, and so on. Most of them appointed him to recover their overdue wages at the Ministry of Foreign Affairs, and one also asked for annuities to be sold. A widow who gave him a general power of attorhey was the exception, in that we cannot testify to her ties with diplomacy. He had obviously made a reputation among employees of the ministry as a reliable proxy, so much so that three of the forms had been drawn in Cairo, Jerusalem, and Tbilissi (Georgia) before being filed in the records of Darasse's customary notary. Choosing him was clearly nothing like an impersonal decision.
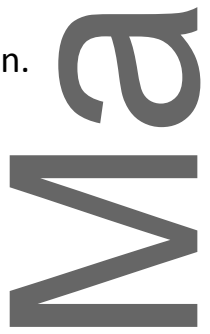

Despite having carefully chosen a case study in which macro events - the French Revolution and the Industrial Revolution - arguably were likely to transform incentives, leading to less interpersonal powers of attorney, we have found little or no support in our data for the simplest modernization narrative of a demise of personal ties and a drastic shift to anonymous relationships. As this storyline was shared by many contemporaries and is very much present, if sometimes implicitly, in historical and economic scholarship today, this is in itself a useful result. We found few

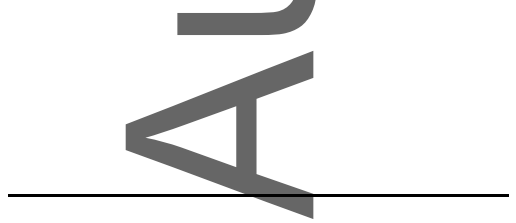

${ }^{47}$ Archives départementales du Nord, $2^{\mathrm{E}} 48 / 172,27$ March 1851.

This article is protected by copyright. All rights reserved. 
significant changes between our periods; and those did not point unequivocally in the direction of increasingly anonymous relationships.

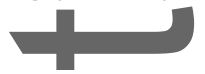

On the basis of the empirical evidence revealed by this study, we cannot rule out that a radical shift in the depersonalization of powers of attorney had occurred before the mid-eighteenth century. This result is consistent with a recent literature uncovering, through careful empirical analysis of contracts, the institutional micro-foundations for impersonal exchange. ${ }^{48}$ In each case, researchers found that incentives for transactions to cross networks arose earlier than other scholars had generally thought.

However, our sources do not paint a picture of a purely anonymous market in which trust relied solely on formal institutions. Our results indicate a complementarity between trust based on preexisting relationships, especially among kin, and formalization rather than a substitution over time. The very use of the most formal contracts - notarized proxy forms - between relatives hints at this. If our results, which generally indicate little change, support one overarching modernization narrative, it would be that of division of labour rather than depersonalization. Changes to that effect appear in our variables related to the phrasing of contracts and to the choice of frequent proxies. We have also identified the limits of one common hidden assumption: the idea that what mattered to the commercial relationship was preexisting ties between two individuals. On the contrary, blank forms and substitution clauses are indications of longer relational chains in which the principal-proxy contract is just one step, in the case of substitutions, or could only be established thanks to one or several intermediaries, especially notaries, in the case of blank forms.

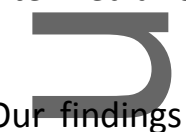

Our findings open several avenues for future research. In particular, a companion article could model theoretically and test the decision-making process of principals, who had at hand two

${ }^{48}$ Hoffman et al., Priceless markets, p. 286; Santarosa, 'Financing'.

This article is protected by copyright. All rights reserved. 
levers to mitigate opportunism in agency: the choice among different types of proxies, such as familial, professional, a blank form, and so on, and the choice of contractual terms and their phrasing. Empirically, more systematically comparing notarial practices across places and across notaries in the same place would shed light on differences in clauses and perhaps on relational chains. Extending our sample across time and zooming in on specific places and social groups may illuminate the extent to which powers of attorney were part of the 'usual business' of a merchant as opposed to an instrument reserved to react to exceptional situations. Understanding when a power of attorney represented a one-time interaction or short-term agency leading to a long-term partnership would require us to look for traces of reciprocation and mutual agency in the principalproxy relationships among merchants. It would elucidate the place of powers of attorney in commercial life, and the tradeoffs of these instruments in view of the menu of contractual devices available to merchants.

\section{Footnote references}

Acker, M. W., Deeds of Franklin County, Georgia, 1784-1826 (Easley, 1976).

Amiaud, A., Le tarif général et raisonné des notaires: étude sur les principes et le mode de rémunération des actes notariés (Paris, 1875).

Antunes, C. and Ribeiro da Silva, F., 'Cross-cultural entrepreneurship in the Atlantic:

Africans, Dutch and Sephardic Jews in Western Africa, 1580-1674', Itinerario:

International Journal on the History of European Expansion and Global Interaction, 35 (2011),pp. 49-76.

Arruñada, B. and Andonova, V., 'Common law and civil laws as pro-market adaptations', Washington University Journal of Law and Policy, 26 (2008), pp. 81-130.

Bairoch, P., Batou, J. and Chèvre, P., Population des villes européennes de 800 à 1850: banque de données et analyse sommaire des résultats (la) (Geneva, 1988).

Bartolomei, A., de Oliveira, M., Eloire, F., Lemercier, C. and Sougy, N., 'L'encastrement des relations entre marchands en France, 1750-1850: une révolution dans le monde du 
commerce?', Annales. Histoire, Sciences Sociales, 72 (2017), pp. 425-60.

Bergeron, L., Banquiers, négociants et manufacturiers parisiens du Directoire à l'Empire

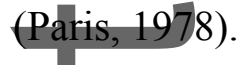

Berry, C. J.Paganelli, M. P. and Smith, C., eds., The Oxford handbook of Adam Smith (Oxford, 2013).

Boigeol, A. and Dezalay, Y., 'De l'agent d'affaires au Barreau: les Conseils Juridiques et la construction d'un espace professionnel', Genèses, 27 (1997), pp. 49-68.

Braudel, F. The Mediterranean and the Mediterranean world in the age of Philipp II, vol. 1, translate by S. Reynolds (New York, 1972).

Carrière, C., Négociants marseillais au XVIIIe siècle : contribution à l'étude des économies maritimes (Marseille, 1973).

Chandler, A. D., The visible hand: the managerial revolution in American business (Cambridge, 1977).

Chassagne, S., Veuve Guerin et fils, banque et soie : une affaire de famille - Saint-ChamondLyon, 1716-1932 (Lyon, 2012).

Cheney, P., Cul de sac: patrimony, capitalism, and slavery in French Saint-Domingue (Chicago, 2017).

Crowston, C., Credit, fashion, sex: economies of regard in Old Regime France (Durham, 2013)

Cyr, M., 'L'activité économique des femmes en Nouvelle-France: étude des procuratrices à Quểbec de 1740 à 1749', in R. Corbeil, A. Hien, and A. Reguigui, eds., Sciences en devenir: actes de la 16e Journée Sciences et Savoirs (Sudbury, 2010), pp. 89-108.

Dalloz, D. and Dalloz, A., 'Mandat', in Répertoire méthodique et alphabétique de législation, de doctrine et de jurisprudence, 30 (Paris, 1853), pp. 624-765.

Deschanel, B., 'Que vaut un négociant? Prix et compétences des commerçants dauphinois, des années 1750 aux années 1820', Cahiers de Framespa, 17 (2014), http://framespa.revues.org/3019.

Dixit, A., 'On modes of economic governance', Econometrica, 71 (2003), pp. 449-81.

Dufournaud, N. and Michon, B., 'Les femmes et le commerce maritime à Nantes (16601740): un rôle largement méconnu', Clio: Femmes, Genre, Histoire, 23 (2006), pp. $311-30$.

Fontaine, L., The moral economy: poverty, credit, and thrust in early modern Europe 
(Cambridge, 2014).

Gervais, P., 'Early modern merchant strategies and the historicization of market practices', Economic Sociology - The European Electronic Newsletter, 35 (2014), pp. 19-29.

Granovetter,M.S., 'Economic action and social structure: the problem of embeddedness', American Journal of Sociology, 91 (1985), pp. 481-510.

Greif, A., Institutions and the path to the modern economy: lessons from medieval trade (Cambridge, 2006).

Grenier, B. and Ferland, C., "“Quelque longue que soit l'absence”: procurations et pouvoir féminin à Québec au XVIIIe siècle', Clio: Femmes, Genre, Histoire, 37 (2013), pp.

\section{$197-225$.}

Grossetti, M., Barthe, J. and Chauvac, N., 'Studying relational chains from narrative material', Bulletin of Sociological Methodology/Bulletin de Méthodologie Sociologique, 110 (2011), pp. 11-25.

Guinnane, T. W., 'Trust: a concept too many', Jarhbuch Für Wirtschaftsgeschichte, 1 (2005), pp. 77-92.

Hancock, D., Citizens of the world: London merchants and the integration of the British Atlantic community, 1735-1785 (Cambridge, 1995).

Hirsch, J.-P., Les deux rêves du commerce: entreprise et institution dans la région lilloise, 1780-1860 (Paris, 1991).

Hoffman, P. T., Postel-Vinay, G. and Rosenthal, J., Priceless markets: the political economy of credit in Paris, 1660-1870 (Chicago, 2000).

Kessler, A., A revolution in commerce: the Parisian merchant court and the rise of commercial society in eighteenth-century France (New Haven, 2007).

Leunig, T., Minns, C., and Wallis, P., 'Networks in the premodern economy: the market for London apprenticeships, 1600-1749', Journal of Economic History, 71 (2011), pp. $413-43$.

Lopez, R. S., 'Proxy in medieval trade', in W. C. Jordan, B. McNab and T. F. Ruiz, eds., Order and innovation in the Middle Ages: essays in honor of Joseph R. Strayer (Princeton, 1976), pp. 187-94.

Lozano Salado, L., 'Dos siglos del comercio gaditano a través de los poderes notariales (1650-1850)', Trocadero, 3 (1991), pp. 25-58.

Marzagalli, S., 'Establishing Transatlantic trade networks in time of war: Bordeaux and the 
United States, 1793-1815', Business History Review, 79 (2005), pp. 811-44.

Molina Jiménez, I., 'Informe sobre las cartas poder de los comerciantes y campesinos del

valle central de Costa Rica (1800-1824)', Anuario de Estudios Centroamericanos, 12 (1986), pp. 97-121.

Molina Jiménez, 1., 'Solidaridades, conflictos y derechos: las cartas poder otorgadas en el

valle central de Costa Rica (1824-1850)', Avances de Investigación, 39 (1988), pp. 164

Mourlon, F. and Jeannest-Saint-Hilaire, A., Formulaire général à l'usage des notaires, juges de paix, avoués, huissiers, greffiers et officiers de l'état civil ... (Paris, 1862).

North, D. C., Understanding the process of economic change (Princeton, 2005).

O'Rourke, K. H., de la Escosura, L. P. and Daudin, G., 'Trade and empire', in S. Broadberry and K. H. O'Rourke, eds., Cambridge economic history of modern Europe, vol. 1, 1700-1870 (Cambridge, 2010), pp. 96-120.

Palmer, J. L., 'Women and contracts in the age of transatlantic commerce', in D. M. Hafter and N. Kushner, eds., Women and work in eighteenth-century France (Baton Rouge, 2015), pp. 130-51.

Pfister, L., 'Un contrat en quête d'identité : jalons pour une histoire de la qualification du mandat, in N. Dissaux, ed., Le mandat: un contrat en crise? (Paris, 2011), pp. 1-38.

Polanyi, K., The Great Transformation: the political and economic origins of our time (New York, 1944).

Poisson, J.-P., 'Introduction à une sociologie statistique des actes de procuration', Journal de La Société Statistique de Paris, 109 (1968), pp. 263-65.

Pothier, R. J., 'Traité du contrat de mandat', in Oeuvres complètes de Pothier (Paris, 1821), pp. $1-203$.

Price, T. E., 'Manuscript sources for nineteenth-century banks and banking in Louisiana and the Lower Mississippi Valley in the Louisiana State University libraries', Louisiana History: Journal of the Louisiana Historical Association, 29 (1988), pp. 65-75.

Ritzer, G., 'Professionalization, bureaucratization and rationalization: the views of Max Weber', Social Forces, 53 (1975), pp. 627-34.

Rosentha1, J, 'The development of irrigation in Provence, 1700-1860: the French Revolution and economic growth', Journal of Economic History, 50 (1990), pp. 615-38.

Santarosa, V. A., 'Financing long-distance trade: the joint liability rule and bills of exchange 
in eighteenth-century France', Journal of Economic History, 75 (2015), pp. 690-719.

Smith, S. B. and Owsley, H. F. C., The papers of Andrew Jackson, vol. I, 1770-1803

(Knoxville, 1980).

Sturtz, L. L., "As though I my self was pr[e]sent”: Virginia women with power of attorney',

in C. L. Tomlins and B. H. Mann, eds., The many legalities of early America (Chapel Hill, 2001), pp. 250-71.

Trivellato,F., The familiarity of strangers: the Sephardic diaspora, Livorno, and crosscultural trade in the early modern period (New Haven, 2009).

Troplong, R., Le droit civil expliqué: du mandate, vol. 16 (Paris, 1846).

Uzzi, B., 'Social structure and competition in interfirm networks: the paradox of embeddedness,' Administrative Science Quarterly, 42 (1997), pp. 35-67.

Xifaras, M., 'Science sociale, science morale? Notes sur la pénétration de l'économie dans la pensée juridique française au XIXe siècle', in J. Kervégan and H. Mohnhaupt, eds., Économie et théories économiques en histoire du droit et en philosophie (Frankfurt am Main, 2004), pp. 185-225.

Weber, M., Economy and society: an outline of interpretive sociology, 2 vols. (1978).

Yates, A., 'Making metropolitan markets: information, intermediaries, and real estate in modern Paris', in H. Berghoff, P. Scranton and U. Spiekermann, eds., The rise of marketing and market research (New York, 2012), pp. 95-125.

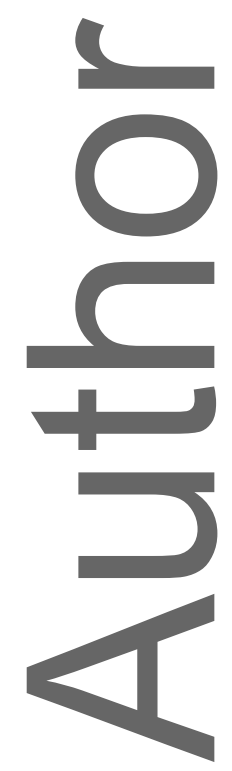

This article is protected by copyright. All rights reserved. 
Table 1. Frequency of powers of attorney by year according to main object and principal's occupation

\begin{tabular}{|c|c|c|c|c|}
\hline & & 1751 & 1800 & 1851 \\
\hline \multirow[t]{3}{*}{ General powers, inheritance, managing land and/or buildings } & Merchant $^{c}$ & $4 \%$ & $4 \%$ & $3 \%$ \\
\hline & Other comm. ${ }^{d}$ & $3 \%$ & $5 \%$ & $6 \%$ \\
\hline & Other ${ }^{e}$ & $13 \%$ & $25 \%$ & $17 \%$ \\
\hline \multirow{3}{*}{ Managing a company } & Merchant & $2 \%$ & $3 \%$ & $2 \%$ \\
\hline & Other comm. & $0 \%$ & $1 \%$ & $1 \%$ \\
\hline & Other & $0 \%$ & $0 \%$ & $0 \%$ \\
\hline \multirow[t]{3}{*}{ Recovering debts or other sums owed } & Merchant & $21 \%$ & $7 \%$ & $5 \%$ \\
\hline & Other comm. & $3 \%$ & $5 \%$ & $4 \%$ \\
\hline & Other & $8 \%$ & $18 \%$ & $14 \%$ \\
\hline \multirow[t]{3}{*}{ Selling annuities or collecting interest } & Merchant & $4 \%$ & $0 \%$ & $2 \%$ \\
\hline & Other comm. & $0 \%$ & $0 \%$ & $5 \%$ \\
\hline & Other & $15 \%$ & $5 \%$ & $18 \%$ \\
\hline \multirow[t]{3}{*}{ Representation in court } & Merchant & $3 \%$ & $1 \%$ & $2 \%$ \\
\hline & Other comm. & $1 \%$ & $1 \%$ & $0 \%$ \\
\hline & Other & $4 \%$ & $2 \%$ & $1 \%$ \\
\hline \multirow{3}{*}{ Commercial tasks } & Merchant & $4 \%$ & $3 \%$ & $1 \%$ \\
\hline & Other comm. & $1 \%$ & $1 \%$ & $1 \%$ \\
\hline & Other & $1 \%$ & $3 \%$ & $3 \%$ \\
\hline \multirow[t]{4}{*}{ Other civil (noncommercial) tasks ${ }^{b}$} & Merchant & $2 \%$ & $2 \%$ & $2 \%$ \\
\hline & Other comm. & $2 \%$ & $2 \%$ & $3 \%$ \\
\hline & Other & $8 \%$ & $8 \%$ & $10 \%$ \\
\hline & & 862 & 828 & 1141 \\
\hline
\end{tabular}

Notes: ${ }^{a}$ Includes selling merchandise and miscellaneous tasks; e.g., representation in bankruptcy or winding up proceedings. ${ }^{b}$ Includes selling land and/or buildings and miscellaneous tasks; e.g., representation before the bureaucracy, accepting a donation, representation in family proceedings, such as for the care of orphans. ' 'marchand' or 'négociant' or 'commissionnaire' in the source denotes wholesale activity and social respectability. ${ }^{\mathrm{d}}$ Includes bankers, brokers, employees of merchants, manufacturers, skilled workers, shopkeepers, master artisans, captains of ships. ${ }^{e}$ Includes lawyers, civil servants, propertied persons, doctors, clergy, etc., along with unknown occupations.

Table 2. Evolution in the relationships between principal and proxy

$\begin{array}{llllll}\text { Year } & \text { Spouses } & \text { Other kin } & \text { Other } & \text { No mention } & \text { No. Obs. } \\ \text { \% in } 1751 & 6 & 16 & 3 & 75 & 632 \\ \% \text { in } 1800 & 10 & 20 & 3 & 67 & 618 \\ \% \text { in } 1851 & 7 & 15 & 2 & 76 & 782 \\ \% \text { in Total } & 8 & 17 & 3 & 73 & 2032\end{array}$

Notes: Calculations exclude blank and filled-in blank forms. 'Other' includes neighbours (c.1\%) along with employees, associates, co-creditors, etc. (c. $2 \%)$.

This article is protected by copyright. All rights reserved. 
Table 3. Regression evidence on the evolution of ties between principal and proxy

\section{(1)}

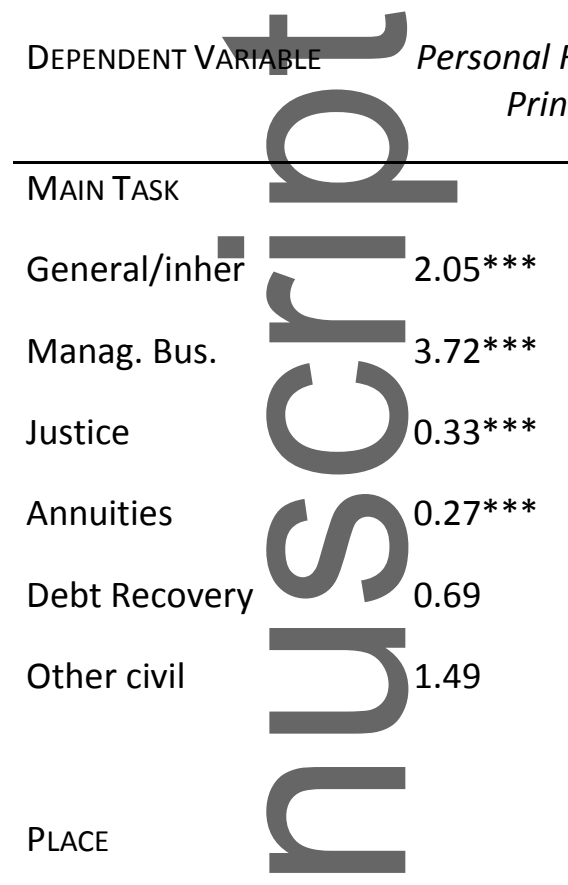

(2)

Homophily

1.10

0.61

$0.37^{*}$

$0.39 * *$

1.27

1.19

$0.35^{* * *}$

1.10

0.59*

0.72

0.61

$0.73^{* *}$

Merchant

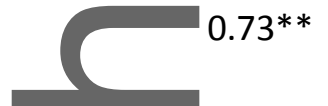

No. PRINCIPALS

SS

2 or more

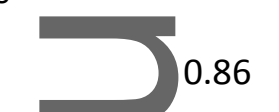

GENDER PRINCIPAL $1.69 * * *$

(3)

Merchant Proxy
$0.43^{* * *}$

$0.27^{* * *}$

$0.21^{* * *}$

$0.44^{* *}$

1.27

0.63

1.22

$0.52^{* *}$

$0.48^{* *}$

1.36

0.82

$4.14^{* * *}$

1.04

0.99

0.88

$1.98^{* * *}$

0.91

$0.46^{* * *}$ 
COHORT

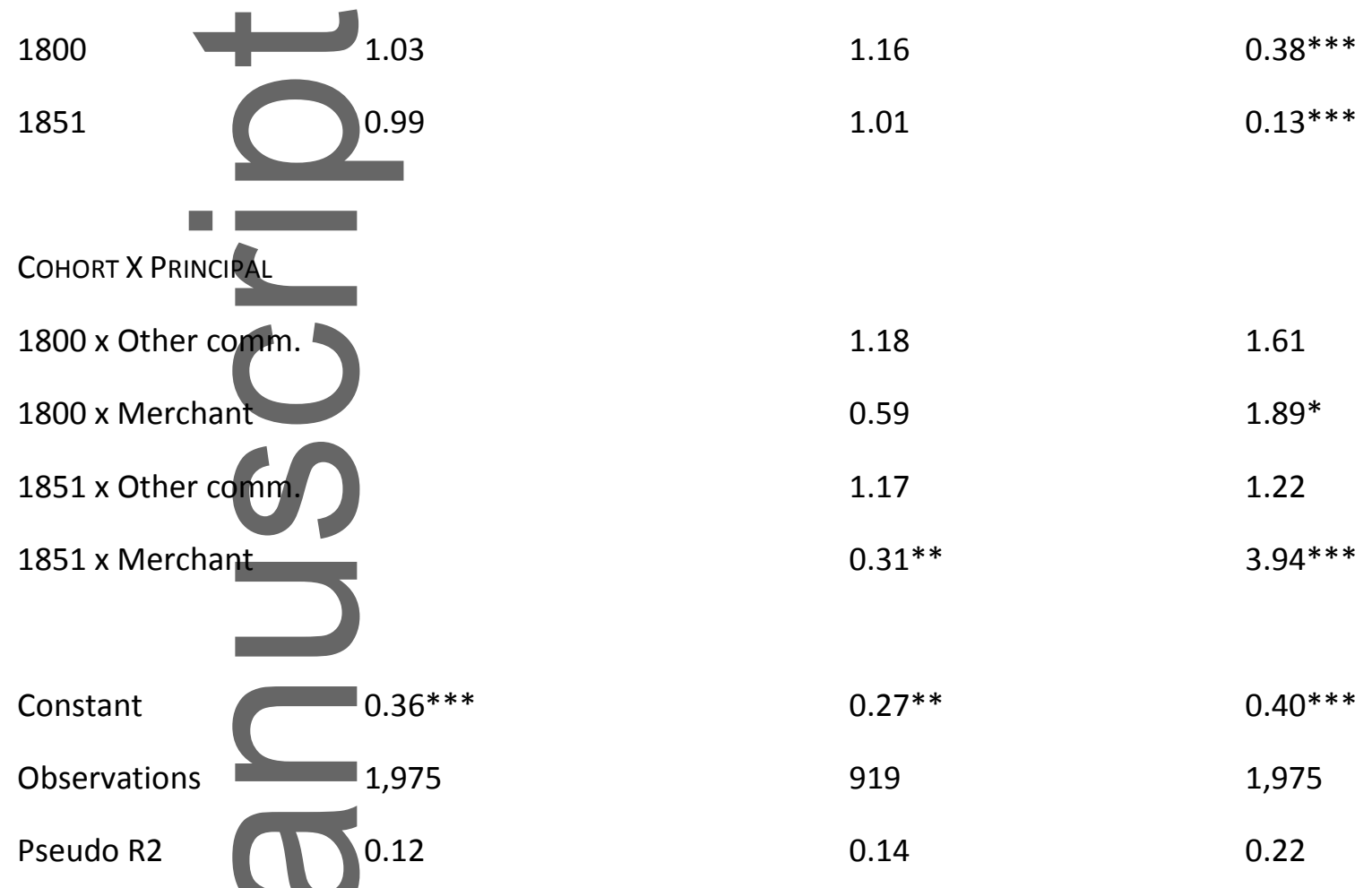

Notes: Estimates reported as odds ratio. ${ }^{* * *} \mathrm{p}<0.01,{ }^{* *} \mathrm{p}<0.05,{ }^{*} \mathrm{p}<0.1$. Reference category: commercial, Lyons, other occupation, 1 principal, male, 1751. The reference category is the one for which the profiles of proxies (relation to principal, frequent proxy, merchant proxy, blank form) were closest to average, except for place and main task. Regressions on full sample, omitting cases with unknown main task, blank and filled-in blank forms. In (2), we exclude observations for which the principals' or proxy's occupation was 'unknown' or 'other (please see online appendix for classifications). We also exclude cases in (2) with a personal relationship between the principal and proxy and frequent proxies.

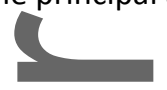

Table 4. Regression evidence on relational chains and the appearance of frequent generalist proxies

\begin{tabular}{lccccc}
\hline & $(1)$ & $(2)$ & $(3)$ & $(4)$ & $(5)$ \\
DEPENDENT VARIABLE & $\begin{array}{c}\text { Blank and } \\
\text { Filled-in }\end{array}$ & $\begin{array}{c}\text { General } \\
\text { Substitution }\end{array}$ & $\begin{array}{c}\text { Partial } \\
\text { Substitution }\end{array}$ & Final Clause & $\begin{array}{c}\text { Frequent } \\
\text { generalist } \\
\text { proxy }\end{array}$ \\
\hline MAIN TASK & & & & 1.39 & $0.46^{* *}$ \\
General/inher & 1.19 & 1.47 & 0.87 & 1.56 & - \\
Manag. Bus. & $0.39^{* *}$ & $2.30^{*}$ & $2.44^{*}$ & 0.83 & 0.34 \\
Justice & $2.13^{* * *}$ & $0.47^{*}$ & 0.55 & &
\end{tabular}

This article is protected by copyright. All rights reserved. 


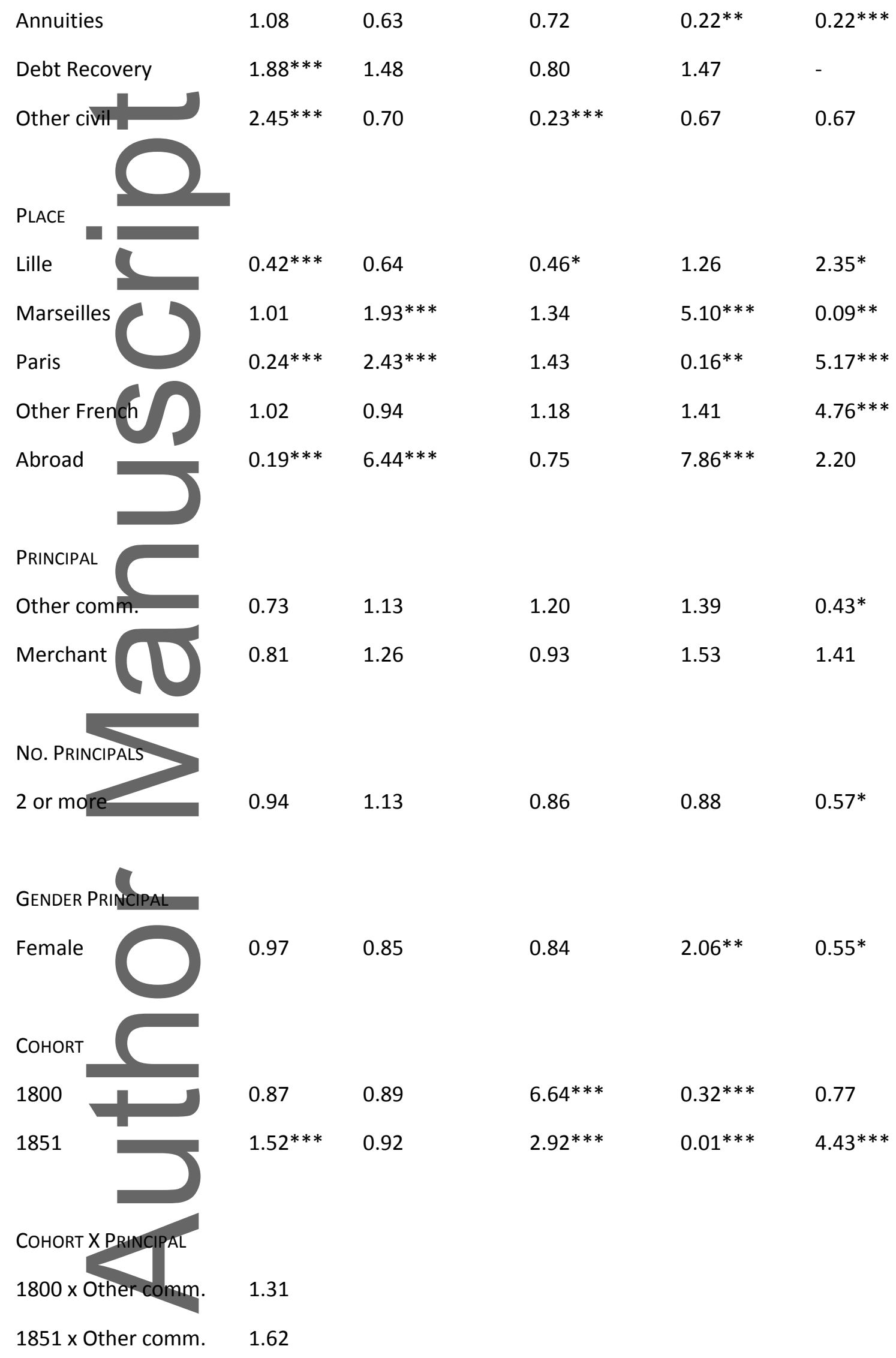

This article is protected by copyright. All rights reserved. 
1851 x Merchant

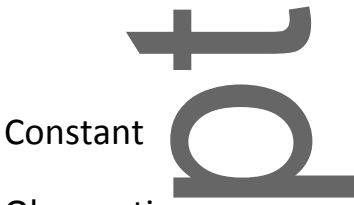

\section{$0.32 * * * \quad 0.62$}

2,748

0.08
862

0.08
$0.13^{* * *}$

862

0.14
$0.34^{* *}$

732

0.36
$0.02 * * *$

1,770

Pseudo R2

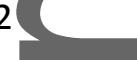

Notes: Estimates reported as odds ratio. ${ }^{* * *}$ Lyons, other occupation, 1 principal, male, 1751. Regression in (1) and (5) on full sample, omitting cases with unknown main task. Regression in (2), (3) and (4) on reduced sample, omitting cases with unknown main task. In (4) the dependent variable is whether the proxy form contained a final clause 'whatever the principal could have done in person' and the regression excludes cases without a final clause. In (5) debt recovery is the reference category because there were no 'commercial' cases with a frequent generalist proxy. Note that there were no 'business management' cases either. Regression in (5) excludes cases with blank forms.

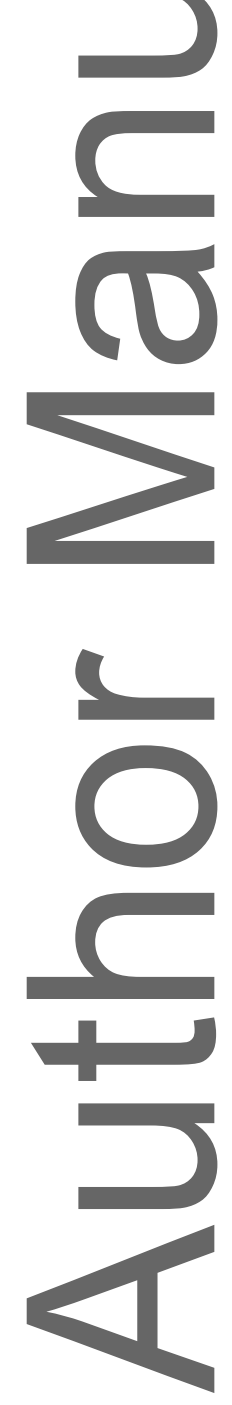

This article is protected by copyright. All rights reserved. 